\title{
Prison Cells, Leg Restraints, and "Custodial Interrogation": Miranda's Role in Crimes That Occur in Prison
}

\author{
Steve Finizio $\dagger$
}

This Comment explores the role that the Supreme Court's decision in Miranda $v$ Arizona ${ }^{1}$ should play in crimes that occur in prison. Following that historic decision, warning an individual of his constitutional rights is a prerequisite to "custodial interrogation." Miranda warnings have become ingrained in our criminal procedure, ${ }^{3}$ recognizable to countless Americans through sources ranging from television shows ${ }^{4}$ to comic strips. ${ }^{5}$ Yet it is not clear when these warnings must be administered to prison inmates.

The traditional approach to Miranda asks whether a "custodial interrogation" has occurred. ${ }^{6}$ The Miranda Court defined "custodial interrogation" as "questioning initiated by law enforcement officers after a person has been taken into custody or otherwise deprived of his freedom of action in any significant way." " A prison inmate is, by definition, deprived of his freedom in a most fundamental way. It would seem, then, that Miranda dictates that an inmate be given warnings before being asked most questions. However, using this traditional approach, many courts have held that the prisoners before them were not "in custody" or were not

† A.B. 1988, Georgetown University; J.D. Candidate 1992, The University of Chicago.

384 US 436 (1966).

2 Prior to any questioning, the Court required that the individual "be warned that he has a right to remain silent, that any statement he does make may be used as evidence against him, and that he has a right to the presence of an attorney, either retained or appointed." Id at 444.

3 Then-Justice Rehnquist stated that "[a]t this point in our history virtually every schoolboy is familiar with the concept, if not the language [of the self-incrimination provision of the Fifth Amendment.]" Michigan $v$ Tucker, 417 US 433, 439 (1974).

'In United States $v$ Yunis, 681 F Supp 909, 924 (D DC 1988), the district court noted that the defendant, a Lebanese national accused of hijacking, "did not grow up watching Hawaii Five-O or Matlock" and thus was not conversant with Miranda."

- See Spider-man comic strip as discussed in Irene Merker Rosenberg and Yale L. Rosenberg, A Modest Proposal For the Abolition of Custodial Confessions, 68 NC L Rev 69, 69-72 (1989).

- See generally Jefferson V. Smith, The Threshold Question in Applying Miranda: What Constitutes Custodial Interrogation?, 25 SC L Rev 699 (1974).

7 Miranda, 384 US at 444 (footnote omitted). 
"interrogated" for purposes of Miranda ${ }^{8}$ It appears that, in reality, Miranda plays a very small role within the walls of the penitentiary.

At first blush, much of the case law seems counter-intuitive. For example, the Fourth Circuit held that a prisoner in handcuffs and leg restraints was not in custody. ${ }^{9}$ The Tenth Circuit held that a prisoner who was locked in his cell was not in custody. ${ }^{10}$ Perhaps even more surprisingly, the Second Circuit held that a prisoner was not "interrogated" when he was brought alone to a small room in leg irons, a belly chain, and handcuffs and asked repeatedly by a prison official what a package contained." While some of these cases reach the correct result, the reasoning employed by the courts in these cases obscures the proper inquiry: whether the institution has turned its coercive powers against the individual inmate.

Section I of this Comment addresses the evolution of the $\mathrm{Mi}$ randa doctrine as it relates to prisons. Section II examines different approaches for applying Miranda's safeguards within prison. The most commonly used approach is the "added imposition" test, which is based upon the traditional custodial interrogation approach to Miranda. Some judges and commentators have also suggested a per se "in custody" rule as an alternative to the added imposition test. Section III examines the nature of the prison environment and the needs of prison administration as they relate to the role that Miranda should play within the penitentiary.

Section IV argues that the concept of "custody". is artificial and misleading when used in the prison context, and proposes a "focus test" to determine when Miranda warnings are necessary. Under this focus test, Miranda warnings are required when prison authorities have focused their attention upon an individual inmate as a suspect to a crime. In recognition of the exigencies of prison administration, this focus test would have an exception based upon the public safety exception now employed by the Supreme Court. In addition, this Comment proposes that prison administrators

\footnotetext{
8 See, for example, Cervantes v Walker, 589 F2d 424, 426-29 (9th Cir 1978) (prisoner questioned as to identity of substance discovered in routine search held not subject of custodial interrogation); United States $v$ Conley, 779 F2d 970, 973-74 (4th Cir 1985) (prisoner questioned about fatal stabbing while waiting to receive medical attention for his own wounds held not "in custody").

Conley, 779 F2d at 973-74.

10 United States $v$ Scalf, 725 F2d 1272, 1276 (10th Cir 1984).

1 United States v Morales, 834 F2d 35, 38 (2d Cir 1987). See Note, Putting the Fifth Amendment Behind Bars: United States v Morales, 55 Brooklyn L Rev 455, 475 (1989).
} 
post blanket Fifth Amendment warnings in order to protect prisoners' rights from abuse. These proposals will better reconcile prisoners' Fifth Amendment rights with the needs of prison administration.

\section{Miranda, Prison Interrogation, and the Supreme Court}

The Supreme Court has not dealt with crimes that occur in prison as a distinct question within its Miranda jurisprudence. This section discusses the principles behind Miranda and subsequent developments in the Miranda doctrine that should help define Miranda's proper role within prison.

\section{A. Unclear and Equivocal: The Principles of Miranda}

Prior to Miranda, courts employed a case-by-case, voluntariness approach to determine the admissability of allegedly coerced confessions. ${ }^{12}$ Courts considered several factors in determining whether a defendant's free will was overcome by police interrogation, including "the undesirability of the police conduct in question; the length of the interrogation; the isolation of the suspect from family, friends and legal assistance; and the age, intelligence, education, and physical and mental condition of the accused."13 The approach precluded involuntary confessions on the theory that they were derived in violation of the Due Process Clause of the Fourteenth Amendment. However, some commentators have criticized the voluntariness approach as being too vague and inconsistently applied, thereby encouraging abuses. ${ }^{14}$

In the face of what the Miranda Court perceived to be ongoing abuses under the due process, voluntariness approach, the Court attempted "to give concrete constitutional guidelines for law enforcement agencies and courts to follow"15 based upon the Fifth Amendment guarantee that no person shall be compelled to be a witness against himself. ${ }^{16}$ After Miranda, this objective standard

\footnotetext{
12 See, for example, Spano v New York, 360 US 315, 323 (1959); Blackburn v Alabama, 361 US 199, 205 (1960); and Rogers $v$ Richmond, 365 US 534, 544 (1961).

${ }^{13}$ Note, New York v. Quarles: The Public Safety Exception to Miranda, 59 Tul L Rev 1111,1112 (1985).

14 "Compared to the Miranda fifth amendment protection, decidedly less protection was available to a suspect under the due process standard." Comment, New York v. Quarles: The Public Safety Exception to Miranda, 70 Iowa L Rev 1075, 1077 (1985).

${ }^{15}$ Miranda, 384 US at 441-42. See also James J. Tomkovicz, Standards for Invocation and Waiver of Counsel in Confession Contexts, 71 Iowa L Rev 975, 978-79 (1986).

${ }_{18}$ The Fifth Amendment provides that "No person ... shall be compelled in any criminal case to be a witness against himself . . . ." US Const, Amend V.
} 
applies to all statements obtained during custodial interrogations not preceded by the prescribed warnings. ${ }^{17}$

The Supreme Court premised Miranda on the assumption that "custodial interrogation" is inherently coercive. Because "custodial interrogation" takes place in private, away from "familiar surroundings," suspects are uniquely susceptible to psychological and physical pressures. ${ }^{18}$ To mitigate the coerciveness of "custodial interrogation," the Miranda Court prohibited the prosecution from introducing into evidence defendants' exculpatory or inculpatory statements made during custodial interrogation unless the prosecution "demonstrate[d] the use of procedural safeguards effective to secure the privilege against self-incrimination."19

B. The Evolution of the Miranda Doctrine and Its Implications for Prison

An understanding of the evolution of the Miranda doctrine is important in analyzing the proper role for Miranda within the penitentiary. The Miranda Court created an exception for on-thescene questioning, ${ }^{20}$ and subsequent decisions have narrowed the definition of "custodial interrogation."21 Other decisions have limited the Miranda doctrine by employing a balancing approach and holding that the warnings required by Miranda are mere prophylactic measures from which the Court can depart. ${ }^{22}$ These developments affect the proper scope of Miranda 'within the prison setting.

17 "The Fifth Amendment Privilege is so fundamental to our system of constitutional rule and the expedient of giving an adequate warning as to the availability of the privilege so simple, we will not pause to inquire in individual cases whether the defendant was aware of his rights without a warning being given." Miranda, 384 US at 468.

18 Id at 461.

18 Id at 444. However, the Miranda Court did not foreclose the use of alternative means of warning suspects of their rights. The Court did insist that the stated warnings were mandatory unless other procedures were shown to be at least as effective. Id at 467 . See also Comment, 70 Iowa $L$ Rev at 1078 (cited in note 14).

${ }^{20} 384$ US at 477.

${ }_{21}^{21}$ Arizona v Mauro, 481 US 520, 527-30 (1987); California v Beheler, 463 US 1121, 1125 (1983); Rhode Island $v$ Innis, 446 US 291, 300-03 (1980); and Oregon v Mathiason, 429 US 492, 495 (1977).

${ }^{22}$ See Michigan v Tucker, 417 US 433, 450-51 (1974); New York v Quarles, 467 US 649, 657 (1984); and Oregon v Elstad, 470 US 298, 308-09 (1985). See also Rosenberg and Rosenberg, 68 NC L Rev at 91 (cited in note 5); Note, Oregon v Elstad: Boldly Stepping Backwards to Pre-Miranda Days? 35 Cath U L Rev 245, 267 (1985); and Comment, 70 Iowa L Rev at 1081-82 (cited in note 14). 
1. On-the-scene questioning within Miranda.

Despite its concerns, the Miranda Court did not "intend[] to hamper the traditional function of police officers in investigating crime." ${ }^{23}$ These traditional functions include seeking evidence in the field and inquiring of citizens to determine whether a crime is in progress or has been committed. General on-the-scene questioning is permissible because "the compelling atmosphere inherent in the process of in-custody interrogation is not necessarily present." Lower courts have continuously applied this on-the-scene exception to questioning conducted by prison authorities in response to crimes that occur in prison. ${ }^{25}$

2. The Supreme Court's application of a balancing test to Miranda.

The Supreme Court has eroded the force of Miranda in a fundamental way. In certain circumstances, when there is no showing of actual compulsion, the Court has abandoned the bright line rule espoused in Miranda in favor of a case-by-case approach.

In Michigan v Tucker, the Court held that Miranda's warnings are mere prophylactic measures designed to protect the right against self-incrimination and are "not themselves rights protected by the Constitution." ${ }^{26}$ In Tucker, the defendant gave the police the name of a witness to his crime before he received Miranda warnings. The Court balanced the interests of the system of justice against the need to provide an effective sanction to protect the defendant's constitutional right, and found that society's needs outweighed the defendant's. ${ }^{27}$ Even though there was "custodial interrogation," there was no violation of the Fifth Amendment because there was no coercion sufficient to breach the right against selfincrimination. ${ }^{28}$

The trend of viewing Miranda as establishing mere prophylactic safeguards that "sweep[] more broadly than the Fifth Amendment itself" continued in Oregon $v$ Elstad ${ }^{29}$ and New York $v$

${ }^{23}$ Miranda, 384 US at 477 .

26 Id at 478 .

${ }^{25}$ See, for example, Cervantes $v$ Walker, 589 F2d 424 (9th Cir 1978); United States v Scalf, 725 F2d 1272 (10th Cir 1984).

26417 US at 444 .

${ }^{27}$ Id at $450-51$.

${ }^{28}$ Id at 448-49.

29470 US at 306. 
Quarles. ${ }^{30}$ In Elstad, the defendant was interrogated twice, once without proper Miranda warnings and again after proper warnings. The court refused to bar the use of the second confession as "fruit of the poisonous tree." 31 According to Elstad, a violation of the Fifth Amendment occurs only when there is "physical violence or other deliberate means calculated to break the suspect's will ...." 32

The Quarles Court created an exception to Miranda for police officers acting on a good-faith concern for public safety. The Court rejected outright a presumption of coercion $^{33}$ and instead relied heavily upon the distinction drawn in Tucker between violations of Miranda's warning requirements and violations of the Fifth Amendment itself. ${ }^{34}$ The Court reasoned that the Fifth Amendment does not prohibit all incriminating admissions, but only officially coerced self-accusations. ${ }^{35}$ Because it had held that Miranda warnings are not required by the Constitution, the Court concluded that public safety was more important than Miranda's prophylactic rules. ${ }^{36}$

In Quarles, police pursued an armed rape suspect into a supermarket. The officer who caught him asked where his gun was. Nodding in the direction of some empty cartons, Quarles responded, "the gun is over there." After officers retrieved the gun, Quarles was formally arrested and read Miranda warnings. ${ }^{37}$ Finding no actual compulsion, then-Justice Rehnquist concluded that the potential danger emanating from a concealed gun in a public place outweighed the benefit to the defendant of proper Miranda warnings. ${ }^{38} \mathrm{He}$ justified the balancing approach by analogy to the exclusionary rule of the Fourth Amendment and the long-recognized exigency exception for searches and seizures. ${ }^{39}$

so 467 US at 657.

31 Elstad, 470 US at 303-04.

s2 Id at 312. See also Stephen J. Schulhofer, Reconsidering Miranda, 54 U Chi L Rev 435, 440-41 (1987).

${ }^{33}$ Quarles, 467 US at $655 \mathrm{n} 5$.

${ }^{34}$ Id at 654 (quoting Tucker, 417 US at 444).

ss See Note, 59 Tul L Rev at 1116 (cited in note 13).

${ }^{38}$ See Irene Merker Rosenberg and Yale L. Rosenberg, In the Beginning: The Talmudic Rule Against Self-Incrimination, 63 NYU L Rev 995, 1043 (1988).

${ }^{37}$ Quarles, 467 US at 651-52. Justice Marshall's dissent emphasized that Quarles was surrounded by three officers with drawn guns and had been frisked and handcuffed when asked where his gun was. Id at 674-75 (Marshall dissenting).

${ }^{38}$ Id at 657.

${ }^{39}$ See Note, 35 Cath U L Rev at 265 (cited in note 22). 
II. Current Approaches to Miranda in the Prison Setting

\section{A. The Supreme Court's Decision in Mathis $v$ United States}

Both the language and the reasoning behind Miranda appear to mandate that prisoners be considered "in custody." If one applies literally Miranda's definition of "custodial interrogation"-questioning initiated after an individual has been deprived of his freedom in any significant way-all prison questioning would seem to trigger Miranda's protections. As the Fourth Circuit has stated, "[a] rational inmate will always accurately perceive that his ultimate freedom of movement is absolutely restrained and that he is never at liberty to leave an interview conducted by prison or other government officials." 40

The Supreme Court seemed to accept such a per se "in custody" approach for prisoners in Mathis v United States. ${ }^{41}$ Internal Revenue Service investigators interviewed Mathis while he was in state prison on unrelated charges and eventually charged him with tax violations. ${ }^{42}$ The Court rejected the Government's arguments that Mathis was questioned as part of a routine tax investigation, and said that it was not significant that he was not being held by his questioners. ${ }^{43}$ The Court felt that Miranda was "clear and unequivocal": if a person's freedom is restrained in any significant way and that person is subject to questioning, then that person is "in custody" and his Fifth Amendment protection against self-incrimination is jeopardized. ${ }^{44}$

However, analysis of the Miranda decision itself, and of subsequent developments in the Miranda doctrine, belie the Court's assertion that Miranda is clear and unequivocal. Accordingly, the Supreme Court's decision in Mathis has not had the broad scope its language would imply. In the subsequent case of Illinois $v$ Perkins, the Supreme Court expressly stated that the "bare fact of custody [might] not in every instance require a warning . . .."45 Lower courts have limited Mathis to its facts: Mathis was questioned by a government agent who was not a member of the prison staff about a matter not under investigation within the prison itself. ${ }^{46}$ As the Mathis Court recognized, in all relevant aspects, the

\footnotetext{
40 Conley, $779 \mathrm{~F} 2 \mathrm{~d}$ at 973.

4391 US I (1968).

42 Id at 2.

43 Id at 4.

"Id at 5 (quoting Miranda, 384 US at 478).

45110 S Ct 2394, 2398 (1990).

${ }^{46}$ See, for example, Conley, 779 F2d at 973; Cervantes, 589 F2d at 427.
} 
interrogation was indistinguishable from a station house interrogation. ${ }^{47}$

B. The "Custodial Interrogation" Approach

1. The threshold inquiry.

Miranda's "custodial interrogation" inquiry is generally broken down into two parts: first, whether the person is "in custody" and, second, whether the questioning constitutes "interrogation." If both prongs are satisfied, an interrogator must provide Miranda warnings. An individual is "in custody" if there is a " "formal arrest or restraint on freedom of movement' of the degree associated with formal arrest" so that a reasonable person would believe he is not free to leave..$^{48} \mathrm{~A}$ defendant has been "interrogated" when there is, first, "a measure of compulsion above and beyond that inherent in custody itself" and second, either express questioning or its functional equivalent" $t^{49}$ that is, police words or actions that are "reasonably likely to elicit an incriminatory response . . .."50

Some courts analyze the question of "custody" first, while others turn first to the question of "interrogation." Regardless of their initial focus, these courts tend to find that no violation of the prisoner's Fifth Amendment rights has occurred.

2. The "added imposition" test and the "on-the-scene" exception.

The "free to leave" test for custody is difficult to apply in prison because a prisoner is always in custody in the purest sense. To replace the "free to leave" test, the Ninth Circuit, in Cervantes $v$ Walker, developed the "added imposition" test to define restriction within prison. The Cervantes court was concerned that if the "custodial interrogation" rule were applied literally, every question asked of a prison inmate in connection with what proved to be criminal activity would have to be prefaced with Miranda warn-

47 The Cervantes line of cases uses slightly different logic to distinguish the Mathis interrogation, arguing that such an interrogation represented an additional imposition on his freedom. See Cervantes, 589 F2d at 428.

48 California $v$ Beheler, 463 US 1121, 1125 (1983) (quoting Oregon v Mathiason, 429 US 492, 495 (1977)).

49 Rhode Island $v$ Innis, 446 US 291, 300-01 (1980). See also Mauro, 481 US 520, 52627.

so Innis, 446 US at 301 . The inquiry focuses on the subjective perception of the suspect rather than on the intent of the police. Id. 
ings. ${ }^{51}$ This would effectively eliminate the "on-the-scene" exception for prisoners. Reasoning that restriction is a relative concept, the Cervantes court defined restriction as implying "a change in the surroundings of the prisoner which results in an added imposition on his freedom of movement." 152 In order to demonstrate "custody," an inmate must show that prison officials have in some way acted upon him to deprive him of his freedom of action in a significant way. ${ }^{53}$ The Cervantes court refused to read Mathis as creating a per se "in custody" rule for prisoners. ${ }^{54}$

In response to a fight, officials ordered Cervantes moved from one cell to another. Prior to completing the move, they sent him, along with his belongings, to a small library for a conversation with the shift commander. Pursuant to standard procedure for moving inmates an officer searches Cervantes's belongings. The officer discovered a small matchbox containing a green odorless substance. Suspecting it was marijuana, he took the matchbox into the library. With the shift commander also present in the small room, the officer asked Cervantes, "What's this?" to which Cervantes replied, "That's grass, man." Cervantes was convicted of possession of narcotics in a county jail.s5

The Ninth Circuit specifically rejected Cervantes's argument that the prison environment was inherently coercive. Rather, the court characterized the contact between Cervantes and the guards as merely on-the-scene questioning that enabled the officer to determine if a crime was in progress. The search of Cervantes' belongings was routine, the incident took place in the relatively benign setting of a library, and the incriminating question was a spontaneous reaction to the discovery of contraband. The court saw "no indication that the questioning took place in a context where respondent's freedom to depart was restricted in any way."

s2 See Conley, 779 F2d at 972.

${ }^{82}$ Cervantes, 589 F2d at 428.

ss To determine whether there has been a change in the prisoner's freedom of movement, the Cervantes approach uses an objective, reasonable person standard which incorporates the same factors used in the "free to leave" test. Relevant factors include "the language used to summon the individual, the physical surroundings of the interrogation, the extent to which he is confronted with evidence of his guilt, and the additional pressure exerted to detain him ...." Id. These factors must be considered to determine "whether a reasonable person would believe there had been a restriction of his freedom over and above that in his normal prisoner setting." Id.

s4 Id at 427.

ss Id.

se Id at 428 (quoting Mathiason, 429 US at 495). 
The Fourth Circuit adopted the added imposition test in United States $v$ Conley. ${ }^{57}$ In Conley, after an inmate was murdered, prison guards searched the other inmates for wounds and discovered that Conley had a wound on his arm. Guards placed Conley in handcuffs and took him to a small conference room in the prison control center to await transfer to the infirmary for medical treatment. There, Conley initiated a conversation with the guards and told them he had tried to help the victim by breaking up the attack. Later, guards returned Conley in full restraints. While restrained, a guard asked him if he was "up to the same old shit again," but Conley denied any involvement in the attack and repeated his story. ${ }^{58}$

The Conley court held that Conley was not "in custody" because the use of leg restraints was part of standard procedure for transferring prisoners. His freedom of movement was therefore no more restricted than that of other prisoners in transit. Additionally, the conversations were brief, the guards questioned Conley as a witness rather than as a suspect, and addressed him by his nickname in a friendly manner. ${ }^{59}$

3. Finding no added imposition despite questioning not onthe-scene.

Because the Cervantes court characterized the questioning as on-the-scene, it left open the issue of whether questioning that could not be characterized as at the scene of a crime requires $\mathrm{Mi}$ randa warnings. The Fourth Circuit explicitly addressed the question of whether the Cervantes court's rejection of a per se "in custody" rule only applies to on-the-scene questioning. According to United States $v$ Cooper, ${ }^{60}$ the "added imposition" approach is not limited to on-the-scene questioning.

The defendants in Cooper were convicted of assaulting another prisoner and a corrections officer. Ten days after the incident the defendants met with a treatment specialist in a prison board room and made incriminating statements. The defendants contended that, because they had not been issued Miranda warnings, the trial court improperly admitted their incriminating statements at trial. The defendants argued that the questioning at issue in

\footnotetext{
87779 F2d 970 (4th Cir 1985).

ss There is no distinction between inculpatory and exculpatory statements as far as Miranda is concerned. Miranda, 384 US at 444.

${ }^{59}$ Conley, 779 F2d at 974.

${ }^{80} 800$ F2d 412, 414-15 (4th Cir 1986).
} 
both Conley and Cervantes was only permissible because such onthe-scene questioning fit within the explicit on-the-scene exception to Miranda. ${ }^{61}$

The court held that the determination of whether a defendant was "in custody" depends on the particular circumstances of the case. The court compared the situation to that in Conley and found the Cooper defendants' circumstances much more benign. At the defendants' own request, officials took them from their cells to a less restrictive area, the disciplinary board room, to talk with a treatment specialist. One door to the room was unlocked. The defendants were not in handcuffs, and they faced a less intimidating prison representative than a guard.$^{62}$ The court found that there was no added imposition on their freedom of movement. ${ }^{63}$ Therefore, the court concluded that the defendants were not "in custody," no "custodial interrogation" took place, and there was no need to administer Miranda warnings. ${ }^{64}$

\section{Focus on "interrogation."}

Conceivably, a court could determine that a prisoner was "in custody," or even that all inmates are per se "in custody," and still find no Miranda violation when the conduct by prison officials does not amount to an "interrogation." This approach is exemplified by United States $v$ Morales. ${ }^{65}$

Morales was in prison for a parole violation. After being transferred to a new facility, Morales was in a medical examination room used for routine physicals for all new inmates. As he pulled up his pants, a package fell to the floor. The physician's assistant conducting the examination asked Morales what had fallen. When the physician's assistant asked to see the package, Morales handed him the package and denied knowing what was in it. The assistant summoned an officer, who field tested the contents and determined that the package contained a narcotic. ${ }^{68}$

In Morales the Second Circuit stated that "custodial interrogation" occurs when a law enforcement official questions an indi-

61 The court acknowledged that the questioning was not on the scene and was willing to assume, without deciding, that this was an interrogation. According to the court, though, the fact that the questioning was on the scene changed only the focus of its inquiry, not its conclusion. Id at 415 .

${ }^{62}$ Id at 414.

os Id at 414-15.

or Id.

as 834 F2d 35 (2d Cir 1987).

${ }^{68}$ Id at $36-37$. 
vidual in a custodial setting that is "inherently coercive" and "tend[s] to undermine the individual's will to resist," and "is conducted by officers who are aware of the potentially incriminatory nature of the disclosures [ ]." ${ }^{\text {"77 }}$ The questioning must represent compulsion which is "above and beyond that inherent in custody itself." 68 The questions asked must be likely to elicit an incriminating response and produce psychological pressures that subject the will of the defendant to the will of the examiner. ${ }^{69}$

The Morales court determined that the medical assistant had no investigatory purpose, but rather had asked what the package was out of curiosity. Since the court found that this was not an "interrogation," there was no need to address the issue of whether the defendant was "in custody." "

C. Problems with the Traditional Custodial Interrogation Approach in Prisons

On a simplistic level, the Cervantes "added imposition" approach is unattractive because it uses common language counterintuitively. On a more fundamental level, this approach focuses inordinately on physical movement, ignoring the psychological pressures inherent in the prison setting. The Miranda court made clear its concern about psychological coercion in interrogation. ${ }^{71}$ A suspect in leg restraints, outside of the prison environment, would clearly be "in custody." Moreover, although such a person may not be "in custody" as that term is understood within the prison, such physical restraint is certainly a source of psychological, as well as physical, coercion. Miranda's concern for mental pressure should retain force.

Also, critics of the "added imposition" approach reject the attempt by Cervantes and its progeny to fashion an on-the-scene exception for prisons. Unlike persons on the street, who are not in custody, inmates have very little freedom of movement. Prison questioning need be neither public nor brief. Interrogation may continue until officials receive the desired response. It is hard to

${ }^{67}$ Id at 38. See also Garner v United States, 424 US 648 (1976).

${ }^{68}$ Morales, 834 F2d at 37-38. See also Innis, 446 US at 300.

${ }^{69}$ Morales, $834 \mathrm{~F} 2 \mathrm{~d}$ at 38. See also Innis, 446 US at 299.

${ }^{70}$ Morales, 834 F2d at 38.

${ }^{71}$ Miranda, 384 US at 448 ("Again we stress that the modern practice of in-custody interrogation is psychologically rather than physically oriented."). 
conceive of a situation where an individual is less able to escape his examiner. ${ }^{72}$

The Morales approach, which focuses on the issue of "interrogation," is also problematic. The Morales decision hinges on the conclusion that the physician's assistant's question was motivated by curiosity. This conclusion fails to recognize that prison officials play multiple roles. In light of the assistant's security training, it is naive to believe that he did not suspect that a package falling from a prisoner's pants might contain contraband. In fact, the assistant admitted that, for a moment, he entertained the thought that the package contained contraband..$^{73}$

The high incidence of crime in prison further complicates an analysis of the examiner's intent. A nationally representative survey of state prison inmates in 1986 found that fifty-three percent had been charged with violating prison rules at least once since entering prison on their current sentence. ${ }^{74}$ Because of the sheer number of violations, prison officials must be aware of the potentially incriminatory nature of almost any encounter with an inmate. The many searches that accompany incarceration testify to this fact.

The Morales court may have placed too great weight on the intent of the physician's assistant and his lack of training in interrogation. Because Miranda was motivated by pro-defendant concerns, the "interrogation" prong of the threshold inquiry emphasizes the defendant's subjective perceptions. Although the intent of the official may have a bearing on whether her words or actions were likely to evoke an incriminatory response, ${ }^{75}$ focusing on the suspect's perception is crucial in order to preclude the government from making use of the restrictive or coercive nature of deten-

72 United States v Cadmus, 614 F Supp 367, 372 (S D NY 1985).

${ }^{73}$ Morales, $834 \mathrm{~F} 2 \mathrm{~d}$ at 38.

74 James Stephan, Prison Rule Violators, Bureau of Justice Statistics Special Report 1 (Dec 1989). "Prison rule breaking involves a wide variety of misbehavior, ranging from minor infractions such as horseplay, failing to follow sanitary regulations, smoking where prohibited, and abusive language toward staff, to serious offenses such as use of contraband drugs and alcohol, possession of a weapon, offering a bribe, extortion, rioting, assault, and murder." Id at 2. Obviously not all infractions are criminal. One survey indicates that about half of all rule violators (in a study of California, Texas and Mississippi state prison inmates) were cited for administrative infractions, a fifth for contraband, and a fifth for some form of violence without injury. The remainder were charged with incidents involving injury, threat, or escape. Id at 2 (citing Joan Petersilia and Paul Honig, Prison Experience of Career Criminals (Rand, 1980)). Ninety-four percent of inmates charged with rule violations were found guilty. Id at 2 .

${ }^{75}$ See Innis, 446 US at 302.03 n 7. 
tion. ${ }^{76}$ Morales's detailed focus on the examiner's intent seems to distort the purpose of Miranda. Moreover, secluded questioning is an example of a common psychological ploy used to pressure the subject to incriminate himself. As the Mauro court emphasized, Miranda is concerned with such psychological ploys. The generally coercive atmosphere of the prison reinforces the pressure created by isolated questioning.

\section{Arguments in Favor of a Per Se "In Custody" Rule}

Advocates of a per se "in custody" rule have criticized the "added imposition" analysis. They assert that decisions which employ the "custodial interrogation" approach turn on details which are "too minor and shadowy." Some per se advocates, like Justice Marshall, argue for a simple application of Mathis. ${ }^{78}$ Others, like Judge Oakes of the Second Circuit, go further and assert that the factors used in the Cervantes "added imposition" test disguise a denial of prisoners' Fifth Amendment rights. ${ }^{78}$

Proponents of a per se "in custody" rule argue that a prisoner is always deprived of his freedom "to a degree associated with formal arrest." rogation. Because inmates tend to be far from the public eye, interrogation in the prison setting is particularly susceptible to abuse. ${ }^{81}$ Per se advocates aver that the proper inquiry is whether the confining atmosphere of prison, coupled with interrogation, actually compelled the inmate to incriminate himself. ${ }^{82}$

Behind the per se argument is the notion that imprisonment robs an inmate of his dignity and self-will in a way that the law should recognize. Institutionalization strips the individual of the support that permits him to maintain his sense of self-worth and his physical and mental integrity. In the routine of institutional life prison officials make most decisions for the inmate. It is impossible for the inmate to be free from restraint or coercion when the thing he covets the most-release-may depend on cooperation with authorities.

As one prisoners' rights advocate has described incarceration:

${ }^{76}$ Mauro, 481 US at 528.

${ }^{77}$ Mathis v United States, 391 US 1, 4 (1968).

${ }^{78}$ Bradley o Ohio, $110 \mathrm{~S} \mathrm{Ct} 3258,3259-60$ (1990) (Marshall dissenting).

${ }^{79}$ Morales, $834 \mathrm{~F} 2 \mathrm{~d}$ at 39 (Oakes concurring).

${ }^{80}$ Beheler, 463 US at 1125.

${ }^{81}$ See Berkemer $v$ McCarty, 468 US 420, 438-39 (1984).

${ }^{82}$ Note, 55 Brooklyn L Rev at 469 (cited in note 11). 
Prisoners must do their time within deprived, restricted, sometimes cruel, even deadly, settings-prisons. ... Above all, prison authorities must keep prisoners under control. . .. they have demanded, often brutally, considerable prisoner compliance. Above all, they have insisted that prisoners accept their inferior status and conform, both in acts and spirit, to prison routines. ... [Prisoners are] low-caste members in the rigidly stratified, relatively totalitarian institution in which all the members above them-guards, other staff members, and the administrators-exercise considerable discretionary power over them and employ extreme, sometimes cruel force to demean and control them. ${ }^{83}$

In such an environment, full of indirect and subtle coercion, inmates can never interact with prison officials as equals.

\section{E. Problems with a Per Se "In Custody" Rule}

1. The per se rule lacks a workable definition of informal conversation.

Per se advocates contend that warnings would not be required for casual and unofficial conversations. Yet they give no indication how to define informal conversations between inmates and guards.

Generally, per se advocates combine the per se "in custody" rule with an aggressive application of Innis, focusing on the inmate's subjective perception. Such an approach makes it extremely difficult to determine how a guard is to know ex ante that a conversation is informal. A conversation will be informal only if it reveals no incriminating information. After every question which leads to an incriminating response, the prisoner will be able to assert that from his perspective he felt compelled to respond to the guard's questions. As the Cervantes line of cases correctly recognizes, given such an approach, it would be necessary to give warnings before practically every conversation.

2. The undesirable side effects of warnings.

Because it is so difficult to identify those informal conversations that do not require warnings, a per se "in custody" rule is likely to lead guards to be overly diligent in administering warn-

s3 John Irwin, The History of the Prison: The Prisoner's Experience (forthcoming). 
ings. Overuse of Miranda can have detrimental side effects. ${ }^{84}$ Warnings may make a contact seem more serious than it actually is, may deter prisoners from responding even though there is no danger of incrimination, and may encourage prisoners not to cooperate when their cooperation is necessary for maintaining order in a volatile situation. This recognition that warnings may inhibit people from giving information was one factor that led the Supreme Court to require that warnings be administered only after an individual had been taken into custody or his freedom had been restricted. ${ }^{85}$ Concern for these undesirable side effects motivated the Quarles Court to create the public safety exception to Miranda. ${ }^{86}$

3. The questionable factual premises of the per se "in custody" argument.

The per se "in custody" approach is based on a series of questionable assumptions. First, even if the prison setting is particularly susceptible to abuse, it is not clear that Miranda warnings effectively counteract that danger. Some commentators suggest that the idea that warnings can dispel compulsion is dubious. ${ }^{87}$ There is evidence that the Miranda warnings, when given, are rarely sufficient to overcome the coercion inherent in custodial interrogation, that arrested parties often do not fully understand the warnings, and that a large majority of suspected persons waive their rights to counsel and to remain silent. ${ }^{88}$ Moreover, Miranda probably has little deterrent effect on the behavior of prison officials when most crimes that occur in prison are handled at disciplinary hearings and therefore are beyond the reach of Miranda's exclusionary rule. The per se approach offers little help for dealing with these difficulties. If the benefits of the per se rule are low, yet the costs to prison administration high, the value of the rule is questionable.

84 Jerold H. Israel, Criminal Procedure, the Burger Court and the Legacy of the Warren Court, 75 Mich L Rev 1319, 1383-84 (1977).

${ }^{85}$ Elstad, 470 US at 309.

${ }^{88}$ Quarles, 467 US at 657.

${ }^{87}$ Schulhofer, $54 \mathrm{U}$ Chi L Rev at 454 (cited in note 32).

${ }^{88}$ Francis A. Allen, The Judicial Quest for Penal Justice: The Warren Court and the Criminal Cases, 1975 U Ill L F 518, 538. 
4. The legal implications of balancing.

As a matter of law, the presumption that "custodial interrogation" is inherently coercive may not be valid in light of the Supreme Court's more recent interpretations of Miranda. Beginning with Tucker, the Court implicitly rejected Miranda's premise that "custodial interrogation" is inherently compelling and that any statements obtained absent the requisite warnings must be presumed coerced and therefore involuntary. ${ }^{80}$ The Court has interpreted the warnings as judicially created safeguards rather than as constitutionally mandated requirements. At least in some circumstances, the Court appears to have returned to a case-by-case voluntariness inquiry ${ }^{90}$ from pre-Miranda cases. ${ }^{91}$

The legitimacy of balancing in the Miranda context is reinforced by the balance the Court explicitly strikes in prisoners' rights cases between an inmate's constitutional rights and legitimate penological interests. The Court repeatedly has established the legitimacy and the necessity of considering the state's interests in prison safety and security. ${ }^{22}$ "There are few cases in which the state's interest in combating the danger posed by a person to both himself and others is greater than in a prison environment, which, 'by definition,' is made up of persons with 'a demonstrated proclivity for antisocial criminal, and often violent, conduct." "993 The state's interest includes ensuring the safety of prison staff and administration, protecting the prisoners' own safety, and as maintaining the proper working of its penal system.

In addition, while prisoners retain the various rights secured by the Bill of Rights, they retain them in forms qualified by the exigencies of prison administration and the special governmental interests that result. ${ }^{94}$ For example, the Supreme Court has held that the Fourth Amendment prohibition against unreasonable search and seizure does not extend to prison cells. ${ }^{95}$

89 See Note, 35 Cath U L Rev at 260 n 102 (cited in note 22).

so Tucker, 417 US at 444-45.

21 See Comment, 70 Iowa L Rev at 1079-80 (cited in note 14).

${ }^{92}$ Washington v Harper, 494 US 210, 223 (1990).

${ }^{93}$ Id at 225 (quoting Hudson v Palmer, 468 US 517, 526 (1984)).

' See Hudson, 468 US at 524 (citations omitted):

[I]mprisonment carries with it the circumscription or loss of many significant rights. . . The curtailment of certain rights is necessary, as a practical matter, to accommodate a myriad of "institutional needs and objectives" of prison facilities, chief among which is internal security.

95 Id at 525-26. 
However, returning to a pure case-by-case approach would revive the problems that the Court hoped to overcome with $\mathrm{Mi}$ randa. The coerced confession approach was too vague and inconsistently applied; no standards emerged to guide the officer in the field, which encouraged abuses and failed to account for more subtle forms of coercion. Today's balancing approach applies after the fact to determine that there has been no invasion of the Fifth Amendment despite a technical violation of Miranda. Balancing does not suggest an alternative set of protections that would justify disregarding Miranda's guidelines.

\section{Implications of the Realities of the Prison Environment FOR THE CURRENT APPROACHES}

The per se "in custody" advocates fail to consider the disruption to the prison system that such a rule would cause. On the other hand, the courts that follow "custodial interrogation" posit that a contrary rule "could totally disrupt prison administration,"96 but fail to explain adequately why such a rule would be disruptive and fail to offer any in-depth view into the nature of the prison system and its implications for Miranda. This section examines the nature of prison to highlight the ways in which the prison environment differs from the environment the Supreme Court contemplated when fashioning Miranda.

A. The Nature of the Prison Environment and the Needs of the Prison Administration

An understanding of the realities of the prison environment is essential to analyzing the role Miranda should play in prison, yet most courts dispose of this issue with a few cursory comments. A closer examination of the prison context suggests not only that the per se advocates misunderstand the disruptive impact of such a rule, but also that any analogy between the penitentiary and the station house or the street is dubious.

As the Supreme Court has recognized, the operation of a correctional institution is "at best an extraordinarily difficult undertaking." 97 Typical is Illinois, where, according to the Chicago Tribune, more than 7,900 maximum security prisoners are "jammed

\footnotetext{
${ }^{86}$ Cervantes, 589 F2d at 427. See also State $v$ Abbott, 21 Utah 2d 307, 445 P2d 142, 144 (1968) (per se rule would make a "shambles" out of custody and the administration of a penal institution).

${ }^{97}$ Wolff v McDonnell, 418 US 539, 566 (1974).
} 
into ... antiquated, gang-controlled and violence-ridden facilities" designed to hold 5,727 inmates. ${ }^{98}$ Moreover, "[a]s crowding increases and rehabilitation programs are spread among more inmates, prisoners [] have more idle time, present more of a danger of revolt and leave the system with less of a chance of turning their lives around."

According to the Supreme Court, "[p]rison life, and relations between the inmates themselves and between the inmates and prison officials or staff, contain the ever-present potential for violent confrontation and conflagration." 100 Therefore, "[t]he interest in preserving order and authority in the prisons is self-evident." "Responsible prison officials must be permitted to take reasonable steps to forestall such a threat, and they must be permitted to act before the time when they can compile a dossier on the eve of a riot." 102 Otherwise, they fail to preserve prison security, which "is [a purpose] 'central to all other corrections goals." "103

Interestingly, the facts of Quarles, in which the Court created the public safety exception to Miranda, demonstrate a threat to safety that may not have been very serious, as compared to those that often arise in prison. The incident occurred late at night in a supermarket. The store was secured and Quarles was in custody. ${ }^{104}$ Yet the Court felt that there was sufficient danger to justify asking Quarles where his gun was before reading him Miranda warnings.

Violent altercations in prison will almost always present a more serious threat to safety than that present in Quarles. ${ }^{105}$ The presence of a concealed weapon in prison is necessarily a dangerous situation that creates a great need for control, and threatens the security of the institution. Maintaining safety within the prison is a "monumental task," 106 for:

ss Rob Karwath, State Prison Crunch Spurs Talk of Lighter Sentences, Chi Trib 1 (Apr 3, 1991). Overall, Illinois detains over 28,000 inmates in facilities designed for 19,289. Id. As of 1990 , there were 771,243 prisoners in the United States, an increase of about $134 \%$ in ten years. Robyn L. Cohen, Prisoners in 1990, Bureau of Justice Statistics Bulletin 1 (May 1991).

90 Rob Karwath, Taxpayers Foot the Bill for Packed Prisons, Chi Trib 1 (Apr 2, 1991).

100 Jones v North Carolina Prisoners' Labor Union, Inc., 433 US 119, 132 (1977).

101 Id.

102 Id at 132-33.

${ }^{103}$ Thornburgh v Abbott, 490 US 401, 415 (1989) (quoting Pell v Procunier, 417 US 817 (1974)).

${ }_{104}$ Quarles, 467 US at 652.

${ }_{105}$ See Comment, 70 Iowa $L$ Rev at 1083 (cited in note 14).

${ }^{108}$ Hudson, 468 US at 526-27. 
[w]ithin this volatile "community," prison administrators are to take all necessary steps to ensure the safety of not only prison staffs and administrative personnel, but also visitors. They are under an obligation to take reasonable measures to guarantee the safety of the prisoners themselves.... [At the same time, they] must prevent, so far as possible, the flow of illicit weapons into the prison; they must be vigilant to detect escape plots, in which drugs or weapons may be involved, before the schemes materialize. ${ }^{107}$

\section{B. Discipline in Prison}

Miranda seems to play a small role within the penal system. Although a large amount of criminal activity occurs in prison, ${ }^{108}$ most criminal activity is handled on a disciplinary level. The courts become involved only in major crimes, like murder, and in crimes committed by inmates serving short sentences.

Although Miranda warnings may be required prior to disciplinary hearings, ${ }^{109}$ prison administrators typically have a wide range of sanctions available to them to punish prisoners for crimes that occur in prison, including reprimand, restrictions of various kinds, extra duty, confinement in a disciplinary cell, and withholding statutory good time. ${ }^{110}$ Minor misconduct is usually handled informally by the inmate's supervisor and to take away good time credit, for example, the inmate must merely be notified. Since $\mathrm{Mi}$ randa is essentially an exclusionary rule, Miranda's protections are only triggered if the defendant goes to trial. ${ }^{111}$ Therefore, $\mathrm{Mi}$ -

102 Id.

108 "During 1981 and the first half of 1982, there were over 120 prisoners murdered by fellow inmates in state and federal prisons. A number of prison personnel were murdered by prisoners during this period. Over 29 riots or similar disturbances were reported in these facilities for the same time frame. And there were over 125 suicides in these institutions." Id at 526 (citation omitted).

108 For example, where disciplinary offenses with which inmates are charged also constitute crimes, or are so closely related to criminal activity that interrogation might elicit evidence of crimes, questioning at disciplinary hearings constitutes "custodial interrogation" and so should be preceded by Miranda warnings. Carter v McGinnis, 351 F Supp 787, 792 (W D NY 1972). However, the Supreme Court has held that prison disciplinary proceedings are not criminal prosecutions, "and the full panoply of rights due a defendant in such proceedings does not apply." Wolf, 418 US at 556. Instead, "there must be mutual accommodation between institutional needs and objectives and the provisions of the Constitution .... Id.

11 Wolff, 418 US at 552.

111 See Sheldon Krantz \& Lynn S. Branham, The Law of Sentencing, Corrections and Prisoners' Rights 372-73 (West, 4th ed 1991), citing Baxter v Palmigiano, 425 US 308, 31516 (1976). Failure to comply with the dictates of Miranda affects only the admissibility of 
randa's protections do little for most prisoners, and prison officials would probably be surprised to learn that Miranda plays any role at all in prison.

Disciplinary proceedings shed light on unique aspects of the prison context that affect the role of the Fifth Amendment. The Supreme Court has acknowledged that:

disciplinary hearings and the imposition of disagreeable sanctions necessarily involve confrontations between inmates and authority and between inmates who are being disciplined and those who would charge or furnish evidence against them. Retaliation is much more than a theoretical possibility; and the basic and unavoidable task of providing reasonable personal safety for guards and inmates may be at stake, to say nothing of the impact of disciplinary confrontations and the resulting escalation of personal antagonisms on the important aims of the correctional process. ${ }^{112}$

The Supreme Court has refused to give inmates the right of crossexamination at-disciplinary proceedings because of the danger of resentment from guards and reprisals from other inmates. ${ }^{113}$ These same dangers complicate the task of investigating crime within prison, even with an on-the-scene exception to Miranda.

The "inmate's code,"114 the unwritten rule that exhorts inmates not to inform on a fellow prisoner, increases the difficulties of investigating prison crime. Gangs have proliferated in prisons, tremendously increasing the threat of reprisal as well as robbery, rape, and violence. In response, administrators have had to rely increasingly on anonymous informer information. ${ }^{115}$ These conditions retard the ability of prison officials to investigate crime effectively in the traditional manner.

statements in a criminal case. If an inmate is therefore questioned by a correctional officer or a disciplinary committee about the circumstances surrounding the inmate's suspected or alleged commission of a disciplinary offense, the inmate's responses properly can be considered during a disciplinary hearing, regardless of whether the inmate was given Miranda warnings before the questioning occurred. Silence can be used against the inmate.

112 Wolff, $418 \mathrm{US}$ at 562.

113 Id at 568-69.

114 "Do not rat on another prisoner" and "Do your own time." See Irwin, The History of the Prison (cited in note 83).

118 Administrators have encouraged "snitching" in new ways, by providing channels for prisoners to inform anonymously, increasing protective custody and rewards, and encouraging an emerging self-serving dog-eat-dog philosophy among the inmates. Id. 
C. Rejection of the Inherently Coercive Presumption

The unique nature of the prison system makes the use of "custodial interrogation" as defined for the station house and the street misleading when applied to prison. "Custody" is such a crucial factor in the traditional analysis because it "convey[s] to the suspect a message that he has no choice but to submit to the officers' will and to confess. ... Moreover, custodial arrest thrusts an individual into ... an interrogation environment created for no purpose other than to subjugate the individual to the will of his examiner."116 The insinuation that "custodial interrogation" will continue until the defendant confesses reinforces this notion. "Custodial interrogation" in the station house serves only one purpose-to get the suspect to implicate himself in a crime. It exists only to break the suspect's will. For that very reason, even without an explicit showing of coercion, the Miranda Court presumed that all such "custodial interrogation" was coercive.

Unlike those in the outside world, prisoners must constantly interact with law enforcement officials, who play a much more intrusive part in inmates' lives than in the lives of ordinary citizens. Prison officials must maintain a level of control over the inmate that would be inappropriate if exerted by a police officer over a citizen on the street. Prison authorities perform a range of functions, including administrative, counseling, disciplinary, and investigative duties. ${ }^{117}$

Despite its repressive nature, the prison is the inmate's home. In this way, prison is fundamentally different from the station house. In his Mathis dissent, Justice White recognized this essential difference, arguing that Miranda rested not merely on physical restraint, but on the presumption that coercion flows from a certain type of custody-police station interrogation of criminal suspects. ${ }^{118}$ While an inmate is confined, he is confined in familiar surroundings. Because an inmate is not "swept from familiar surroundings" when questioned in the prison, he is not faced with the

${ }_{118}$ Minnesota $v$ Murphy, 465 US 420, 433 (1984) (quoting Miranda, 384 US at 457).

117 See Wolff, 418 US at 562 ("Although there are very many varieties of prisons with different degrees of security, we must realize that in many of them the inmates are closely supervised and their activities controlled around the clock. Guards and inmates co-exist in direct and intimate contact. Tension between them is unremitting. Frustration, resentment, and despair are commonplace. Relationships among the inmates are varied and complex .....").

${ }_{118}$ Mathis, 391 US at 7. 
same pressures a citizen in the outside world faces when taken into police custody.

While the prison environment may be repressive, it does not exist simply to compel the individual to incriminate himself. Questioning within the prison system that might meet the literal definition of "custodial interrogation" may have other legitimate purposes. Prison custody should not be considered analogous to police custody unless its purpose is to subjugate the prisoner's will to that of her examiner. Prison questioning, without more, is not the same as "custodial interrogation" as that term was understood in Miranda.

\section{Proposals}

Ultimately, the purpose of Miranda is to protect the rights guaranteed by the Fifth Amendment. The Fifth Amendment is absolute; even an inmate cannot be compelled to be a witness against himself. The goal of this Comment is to propose a method of protecting this right while meeting the needs of the prison system. Because the Supreme Court has said that Miranda warnings are procedural safeguards, and not constitutional rights, those procedures can be altered to meet the particular needs of the prison environment.

Unfortunately, there is not a clearly discernible rationale behind the Fifth Amendment to guide an effective procedural safeguard for use in prison. The Supreme Court has rejected efforts to use possible rationales for the Fifth Amendment to define procedure. As the Court has explained, "the privilege against self-incrimination enjoined by the Fifth Amendment... stands in the Constitution for entirely independent reasons." 110 The difficulty of trying to articulate clearly the purpose behind the Fifth Amendment is illustrated by examining several possible purposes for the privilege against compelled self-incrimination. ${ }^{120}$ None help formulate an effective safeguard for the prison context.

Among the purported rationales for the Fifth Amendment are protecting the individual from the power of the government and preserving the individual's right to privacy. ${ }^{121}$ Yet, by imprisoning him, society has chosen to place the individual under the power of the government and has limited his right to privacy. Other sug-

\footnotetext{
110 Allen v Illinois, 478 US 364,375 (1986) (rejecting reliability of the fact finding process as a basis for the Fifth Amendment).

${ }^{120}$ See Note, 35 Cath U L Rev at 245-46 (cited in note 22).

${ }^{121}$ See Murphy 0 Waterfront Comm'n of New York Harbor, 378 US 52 (1964).
} 
gested rationales for the Fifth Amendment include ensuring the credibility of evidence and safeguarding the accusatory nature of the criminal justice system. ${ }^{122}$ However, safeguarding the integrity of the judicial system and ensuring the reliability of evidence are concerns only when a prosecution takes place. As the discussion above indicates, crimes in prison are often handled through disciplinary procedures instead of prosecutions. A limited use of $\mathrm{Mi}$ randa is better than none at all, as is essentially the case now. Judge Oakes's accusation that the current custodial interrogation analysis actually masks a denial of prisoners' Fifth Amendment rights reinforces this conclusion. ${ }^{123}$

A. Shift in Focus from Generalized Investigation to the Inmate As Suspect

It is necessary to identify the element which converts innocent conversation into "interrogation" that implicates the Fifth Amendment. That line is crossed when the government's sole purpose becomes breaking the will of the individual. While that moment is traditionally reached when an individual is "in custody" and "interrogated," those concepts are murky and difficult to define within the prison context. Prison officials must have the ability to perform the traditional police function of investigating crime. $\mathrm{Mi}$ randa's general on-the-scene exception must retain its force within the walls of prison.

Within the prison setting, then, Miranda warnings should be required when the government has turned its coercive powers against the inmate in order to get him to incriminate himself. That is, Miranda should apply when there is no longer a general investigation but rather a focus on a particular inmate.

This proposed test is reminiscent of the focus test originally used by the Supreme Court in Escobedo v Illinois ${ }^{\mathbf{1 2 4}}$ to determine when the Sixth Amendment right to counsel attaches.

The Supreme Court attempted to reconcile the concepts of focus and "custodial interrogation" in Miranda by explaining that "custodial interrogation" is what the Court meant by focus in Escobedo. ${ }^{125}$ Later, in Beckwith $v$ United States, ${ }^{126}$ the Court re-

122 Id.

${ }^{123}$ Morales, 834 F2d at 39 (Oakes concurring).

124378 US 478, 490-91 (1964) (Sixth Amendment implicated when an investigation has ceased to be a general inquiry of an unsolved crime and has begun to focus on a particular suspect).

${ }^{125}$ Miranda, 384 US at 444 n 4. 
jected the use of a focus test to mark the point when Miranda warnings are needed. In that case, a taxpayer was interviewed at his home by the IRS. The defendant argued that because the investigation had focused on him, he should have received warnings. The Court rejected that argument, noting that the element of "custody" was an essential requirement of Miranda. ${ }^{127}$ The unique nature of the prison setting, however, should distinguish Beckwith. A focus test should be applicable within prison because there is always an element of custody.

This focus inquiry limits the importance of the "custody" prong of the traditional test. Moreover, it alters the "interrogation" prong. Instead of inquiring whether the guards should have known their comments were reasonably likely to elicit incriminatory responses, courts should inquire whether the officers were treating the inmate like a suspect.

One way to determine whether a prisoner is being treated as a suspect would be to compare the treatment he receives to that of a suspect on the street or at the station house. Therefore, the notion of "custody" would not be completely irrelevant to this focus test. The factors that courts use now to determine "custody"-additional restraint beyond what is normal in the setting, the language used to summon the person, the physical surroundings of the interrogation, the extent to which the person is confronted with evidence of his guilt, and the additional pressure exerted to detain him-would surely help indicate whether a prisoner had become a suspect.

\section{B. Use of the Focus Test}

Focus is admittedly a vague concept and somewhat difficult to define in prison. The multiple roles played by guards further complicate the focus inquiry. Yet courts routinely undertake such subtle factual determinations. For example, the Morales court determined that the physician's assistant had no investigatory purpose, and the Conley court specifically noted that the guards treated Conley as if he were a witness and not a suspect. Another example was provided by the court in $S c a l f,{ }^{128}$ which pointed to facts that indicated the guard was not conducting an investigation.

\footnotetext{
128425 US 341 (1976).

${ }^{127}$ Id at 347 .

${ }^{123} 725$ F2d 1272.
} 
In Scalf, the guard testified at the time of the questioning that he was not conducting an investigation, but was merely concerned about what was going on. According to the guard, Scalf was not "in custody" or under arrest, but was being treated just like any other prisoner. If Scalf had been arrested, he would have been taken out, strip searched, and moved to a holding cell. ${ }^{128}$

The focus test can be applied to the facts of the other cases discussed above to determine whether the inmates involved should have received Miranda warnings. For example, the court's conclusion in Cooper was based on the fact that the inmates were in a relatively unrestricted setting when they incriminated themselves. The real inquiry should have been whether the treatment specialist suspected that they were involved in the assaults and was investigating those crimes at the time of the meeting. The defendants had already been charged with assault; they were clearly identified as suspects to the assault, and under the proposed focus test, should have received Miranda warnings before such questioning.

The circumstances in Conley are more ambiguous. The court concluded that the guards questioned him as a witness rather than as a suspect. On the other hand, prison officials were aware of his wounds, which indicated he was involved in the murder. A guard asked him whether he was involved. Moreover, the Cooper court stated that the facts of the Conley case "clearly reveal that Conley was removed from his cell not only for medical treatment but also for questioning as a suspect." ${ }^{130}$ If that characterization is correct, Conley had become the particular focus of an investigation and should have received Miranda warnings.

On the other hand, it is difficult to say the defendant in Cervantes was the subject of an investigation. Admittedly, the officer suspected that the substance in the matchbox found among Cervantes's belongings was marijuana and the officer confronted Cervantes with that evidence. Yet the officer's reaction could be seen as an immediate reaction to his discovery, and his question as an effort to determine what was happening. No formal investigation existed. Seen in that light, Cervantes appears to have been a valid application of the on-the-scene exception to Miranda.

129 Id at 1274.

${ }^{130} 800$ F2d at $415 \mathrm{n} 2$. 
C. Prison Administration Exception

The same concerns which motivated the Court to create the public safety exception are present when a weapon is unaccounted for within a prison. The use of balancing seems particularly appropriate in the prison setting. The needs of prison administration are great and clearly limit prisoners' rights. Moreover, the prison atmosphere is explosive and violent; control and discipline are of paramount importance. The ability to ask questions quickly and get prompt answers is essential. The inappropriate use of Miranda warnings might encourage prisoners not to cooperate at a moment when there is no danger of self-incrimination. For these reasons, prison officials should have wide latitude for asking questions in order to defuse potentially dangerous situations when a weapon is unaccounted for or a riot is imminent.

Yet such an exception necessitates a case-by-case approach, which critics find to be overly vague and inconsistent. Moreover, the fear of abuse is particularly acute in the prison setting because of the ease with which prison officials could claim the need for this exception. Nevertheless, the broad prison administration version of the public safety exception that I am proposing need not be so vague. First, a prisoner can always show actual compulsion. Second, the Supreme Court has clarified the meaning of the public safety exception in ways that suggest guidelines for managing the exception. ${ }^{131}$

The Court has described the public safety exception as a narrow exception for "pressing public safety concerns"132 created by "imminent danger" to the public safety. ${ }^{133}$ This suggests potential guidelines to remedy the vagueness in the public safety exception in the prison context. While taking into account the officer's training and experience, the existence of the prison administration exception should meet a standard of reasonableness. ${ }^{134}$ The danger should be substantial. This inquiry into the substantiality of the threat could look at such factors as the type of weapon involved, the physical and mental state of the prisoner, the potential degree of harm, and the number of potential victims. ${ }^{135}$ Moreover, the threat must be imminent. ${ }^{138}$ Finally, the availability of a reasona-

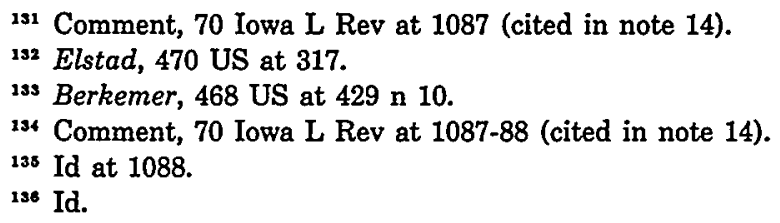


ble alternative should be considered to determine whether disregarding Miranda was necessary. ${ }^{137}$

The facts of Scalf demonstrate the proper role of the prison administration exception. Scalf was convicted of assault with a deadly weapon and conveying a weapon from place to place within a federal penitentiary. Scalf had attacked a fellow inmate with two handmade knives. After the attack, guards locked all the prisoners in their cells. From outside his cell, a guard asked Scalf, "What's the problem?" or "What's going on?", and Scalf incriminated himself, saying he didn't like the victim. The officer then asked Scalf what he did with the knives, and Scalf replied that threw them out the window. Citing Cervantes, the court concluded that Miranda did not apply because Scalf was questioned on the scene of a crime. ${ }^{138}$

This holding is justified by the prison administration exception. Because it was imperative that the guard locate the weapons, he should not have had to give Scalf Miranda warnings before asking where the knives were.

\section{Blanket Warnings}

In recognition that the likelihood that courts may be lenient in applying a focus test, and overly willing to apply the prison administration exception, this Comment also suggests blanket warnings as a method of further protecting inmates' rights. These warnings can be thought of as reminders, or as an effort to educate inmates, so that they are always aware of their rights.

In most cases, blanket warnings should be sufficient protection for inmates and should provide a viable alternative to requiring Miranda warnings before every conversation. Prisoners have extensive exposure to the legal system through arrest, prosecution and incarceration. Although this exposure cannot be said to create an understanding of their rights sufficient to constitute a full, knowing and intelligent waiver ${ }^{139}$ of them, that exposure does let one assume that prisoners have some awareness of their rights. Prisoners therefore need not be expressly informed of those rights before every conversation with an official in the prison system.

Courts have recognized that inmates' knowledge and experience varies from those of citizens at large. For example, in Scalf,

137 Id.

138 725 F2d at 1276.

${ }^{139}$ See Johnson v Zerbst, 304 US 458, 468 (1938). 
the district court suggested that Scalf knew what the prison's investigatory procedure was and recognized that he was not under investigation, because he had been subject to that procedure in the past. ${ }^{140}$ This knowledge should justify providing inmates with different procedural safeguards to protect their Fifth Amendment rights.

Blanket warnings could take varying forms. Officials could require that inmates read and sign written warnings upon entry or they could post notices of prisoners' rights on the walls at conspicuous locations..$^{141}$ Exposure to blanket warnings would not constitute a waiver of Miranda rights, but would serve to dispel any pall of coercion arising from the myriad informal conversations with law enforcement officials that make up a prisoner's daily routine. Signs giving these blanket warnings need not be omnipresent; frequent warnings might have the undesired effect of chilling. even that conversation necessary for prison administration and yet incriminating to the inmate. Given the generally limited nature of inmates' rights, a system of blanket warnings should be sufficient protection for conversations that are not protected by the focus test or that fall under the prison administration exception outlined in this Comment.

\section{CoNCLUSION}

The singular nature of the prison setting suggests that the procedure for protecting the Fifth Amendment be different in prison. Miranda warnings need not play a large role within the prison setting. The warnings currently do little to protect prisoners' rights, but have the potential to hamper the traditional investigatory function of law enforcement officials as well as seriously disrupt the administration of the prison. Because Miranda's safeguards are not constitutional in dimension, it is permissible to limit Miranda procedure within the prison context. Prison officials should have the same latitude as do police on the streets properly to investigate crimes. Additionally, due to the volatile nature of the prison environment, prison officials should be allowed an exception to Miranda, based on the public safety exception, when the needs

140 Scalf, 725 F2d at 1275.

141 The ABA Standards relating to the legal status of prisoners suggest a similar approach for informing inmates of prison rules: "a personal copy of the rules for each prisoner and an oral summary of their substance, in all languages spoken by a significant number of prisoners, should be provided upon entry to the institution." American Bar Association, Standards Relating to the Legal Status of Prisoners 3.1(b) (1981). 
of prison administration demand that questions be answered immediately.

Prisoners have a right not to be compelled to incriminate themselves. Their awareness of that right will be fostered by general reminders given when they enter the prison or posted in common areas. Moreover, once an inquiry shifts from a general investigation to focus on a particular suspect, fresh Miranda warnings should be required. Ultimately, a prisoner is always free to show that actual compulsion took place. This approach should overcome the drawbacks of the per se approach, while providing clearer guidelines than a voluntariness test. This approach would also justify disregard of Miranda warnings by prison officials before the myriad conversations that take place within the prison setting. On the other hand, a focus test is broader than the strict added imposition test now commonly used, and would offer protection to a defendant at the moment he truly needs it-when he has become the suspect of a crime. In this way, the test would be more true to the concern in Miranda for psychological pressures and would better reconcile the realities of prison with the desire to protect inmates' Fifth Amendment rights. 